\title{
Continuing the debate on teacher autonomy: A capabilities perspective
}

\section{Edwin Darrell de Klerk}

Senior Lecturer, Philosophy in Education, Sol Plaatje University, Kimberley, South Africa

edwin.deklerk@spu.ac.za

https://orcid.org/0000-0003-0218-5371

\section{Emma Priscilla Barnett}

Lecturer, Policy and Comparative Studies, Sol Plaatje University, Kimberley, South Africa

emma.barnett@spu.ac.za

https://orcid.org/0000-0002-0303-4594

(Received: 12 January 2020; accepted: 5 September 2020)

\section{Abstract}

Whereas much has been written about initiatives to empower teachers, scholars agree that the capabilities approach, which is an important method for empowering teachers in the arena of autonomy, requires continued research. Our aim in this research paper is, therefore, to continue the debate on fostering teacher autonomy from a capabilities perspective. We present a South African education policy analysis in which it can be seen that capabilities may empower teachers to be agents of autonomy. Having employed a capabilities approach, our study shows that possibilities exist for deepening thinking about teachers' autonomous education practices in general. The findings show that teachers should focus on self-attention and care for the self to become autonomous beings. The results show that empowering teachers to be autonomous may be regarded as a robust paradigm that can be used even as development challenges and educational priorities shift.

Keywords: agency, autonomy, capabilities approach, South African education policy, teacher empowerment

Knowledge is like a garden: if it is not cultivated, it cannot be harvested. (African proverb)

\section{Background and rationale}

While planning this article, we reflected on our past experiences as teachers so as to explore the extent to which we opened ourselves up to educational development. This is our story. 
When we qualified as teachers in the 1990s, we were very much what Foucault (1979) considered docile professionals. To be docile means to comply with the prerequisite that individuals act as skilled professionals who perform duties submissively in order to be labelled high-quality, detailed, and precise (De Klerk, 2014). Subsequently, we were part of a teaching corps that became a set of scrutinized individuals whose specialized activities were managed to control what we were doing, as well as individuals who complied with government policy requirements. We have been meticulous and hard-working while exhibiting high levels of commitment to our work. Having been submissive subordinates, we realised that we were fully compliant with the rules of education policy; we seldom probed the boundaries placed on our own autonomy and capability, among others.

The notion of autonomy came into philosophical prominence for the first time in the work of Immanuel Kant, who was strongly influenced by the writings of Jean-Jacques Rousseau on moral freedom. Although Rousseau did not use the term "autonomy" in his writings, his views on moral freedom have a clear relation to his (1761) understanding of autonomy, articulated as "obedience to the law one has prescribed to oneself" (p. 176). Kant's view points to the capacity of human beings to be independent, to exercise freedom of the will, to refuse to conform to convention, and even to ignore convention.

Capability refers to an individual's freedom to use opportunities to choose what to be and what to do. This implies that individuals can live a life that they can value (Sen, 1992). Importantly, a link between the notions of autonomy and capability indicates that individuals are enabled to decide freely their own path of development in their careers (Binder \& Binder, 2016) in that they should be willing to pay attention to the self and be capable of taking care of the self (Rytzler, 2019). While self-attention implies adopting knowledge and capabilities relevant to an individual's own development (Stiegler, 2010), care of the self implies that individuals use their acquired knowledge to transform themselves in an autonomous manner (Foucault, 1981), in this case, in the field of education.

Throughout our careers, we have been engaged at different levels of education. We have carried out our duties as teachers, department heads, deputy heads, and chief executives while teaching at primary and secondary schools. Because of the nature of our employment and despite creating many opportunities for our colleagues to plan on their own and engage in autonomous decision-making processes, we have realized that we have been only partially effective in promoting values such as independence, self-determination, and professionalism. We engaged in educational activities such as organising workshops and running professional development sessions to give teachers the opportunity to understand their strengths and weaknesses, their potential for growth and personal development, as well as their teaching and learning values. Nevertheless, as Keddie and Mills (2019) have noted in a different context, generally, we and our peers have been too careful to act as autonomous people given that we adhered closely to curriculum implementation-based goals and followed educational policy regulations, despite the opportunities for personal autonomous growth.

We obtained degrees up to doctoral level, mostly through part-time studies. We are currently teaching at a South African university in philosophy studies in education. It is expected that 
we should be closely involved with national policy procedures to determine how policy makers formulate specific policy statements, such as those that refer to self-government and the standing of teachers as professionals. Then we began to read research carried out by Barfield et al. (2001), Little (1995), Smith (2001) as well as Baxen et al. (2014). While reading the works of these scholars, our interest in exploring discourses on philosophy and policy research in schooling, among other topics, deepened. It is this special interest in teacher autonomy and capabilities that prompted us to write this paper because we realised that human self-worth should be regarded as grounds for the development of autonomy and fundamental ethical self-esteem by individuals themselves while opportunities for autonomy should be created by the environment (such as the school, in this instance, in which individuals find themselves (Hill, 1991). However, although the autonomy of teachers has been linked to professional development, efficiency, and their enablement, there is much room for the reinforcement of arguments for their autonomy (Wilches, 2007, in Wermke et al., 2019) from a capabilities perspective.

\section{Applying the capabilities approach to empower teachers}

The capabilities approach provides a standardised structure for social assessment by highlighting the value of life and the welfare of individuals (Powell \& McGrath, 2014) which can, in our view, be seen as a kind of declaration of the self-esteem of teachers. Powell and McGrath (2014) have stated that the emphasis of the capability approach is on providing people with tools to live a life that they value. In doing so, teachers may become agents in their own lives as well as in the educational settings in which they find themselves. In response to the views of Powell and McGrath (2014), we draw on the opinions of Nussbaum (1992) who, on the one hand, asserted that the concept of capabilities signifies a person's valued power that can and should be understood in social action. On the other hand, Sen (1992) indicated that capabilities suggest tangible prospects and authentic sovereignty to achieve anticipated ends (see Crocker, 1992, in Tobias, 2005). While Sen (1992) has contended that Nussbaum's (1992) view embodies a probable, but not indispensable, position in a broader capabilities approach, the former has supported the idea that the determination of a set of marginal functions favourable to wellbeing offers a foundation for public policy. Education policy, as an object of public action can be seen to be the development of the capability of people to assume respected and appreciated doings and become respected and appreciated beings (Sen \& Drèze, 1989, in Tobias, 2005).

Sen $(1999$, p. 4) argued further that the "achievement of development is reliant on the free agency of humans" and that "the expansion of freedom is viewed as both the primary end and the principal means of development" (p. 36). Here Sen's fundamental belief is that individuals should understand agency and be visualized as agents, implying that individuals (including teachers) need to be empowered to perform in the world so as to do and to be. Therefore, by applying the capabilities approach to empower teachers, we support Foucault's (1984/1985) view that one should reason differently, rather than contend that what one knows should be regarded as authentic thought. We argue that Foucault's view should be interpreted as an inquiry into definitive certainties as well as a refusal of grand narratives. Some authors 
(Forghani et al., 2015; Jodamus, 2017) have argued that the refusal of ultimate truths, according to postmodernism, is a celebration of multiplicity and dissimilarity that leads to a much more uncertain and less permanent positioning of bias.

Significant to this deliberation is how the thoughts of Sen (1985), Foucault (1980/1989), and Nussbaum (1992) are interrelated in a discussion of the capabilities approach in terms of teacher autonomy and agency. Whereas Nussbaum argued that capabilities signify a person's valuable powers that can and should be realised in human activity, Sen (1985) insisted that capabilities imply real opportunities and actual freedoms to achieve desired ends. However, Foucault's (1980/1989) thought regarding limit-experience that implies an ethics of selfcreation, complements Nussbaum's and Sen's ideas about the capabilities approach. Considering Foucault (1980/1989), Nussbaum (1992), and Sen (1985), we argue that teachers should use their powers and the opportunities available to them to develop themselves. In so doing, they would exercise agency and autonomy in that "agency freedom is freedom to achieve whatever the person decides he or she should achieve" (Sen, 1985, pp. 203-204). From a Kantian perspective, this implies that teachers have the capability to balance power exerted over them (by means of policy regulations) and suggests how they conduct themselves in an autonomous manner through independent choices (Kant, 1797/1991).

Although in this paper we intend to build on the theory of the capabilities approach to foster teacher autonomy, such an approach has some empirical undertones. Bringing one's own voice into an application of the capabilities approach, aligns with Baldini's (2019) view that through words, individuals can recognize themselves in their capabilities and can then reflect on themselves; we will return to this presently.

Teacher autonomy is a key component of successful schooling and teacher career development as Parker (2015) and Wermke et al., (2019) have noted. Although teacher autonomy depends on several circumstantial aspects such as educational background and the effect of education policy (Mølstad, 2015; Wermke \& Forsberg, 2017; Wermke \& Hösfält, 2014), autonomy should be observed as teachers' independence, ability, and the possibility of achievement in diverse spaces in their lives (Parker, 2015). Thus, an analysis of South African education policy can be regarded as a way of showing how policy can be put into practice to empower teachers in relation to their autonomy.

\section{An understanding of what constitutes education policy}

To understand what education policy is comprised of, Ball (1993), following Foucault (1977), set out a definition that emphasised the dual conceptualisation of policy as text and also as discourse. The observation of policy as text is founded on seeing policy opinions as delineations that are encrypted in multifaceted ways while also being decrypted in manifold ways (Ball, 1993). Ball has asserted that when meanings are found in policy documents, they represent subordinate modification, and this exposes them to clarification and reinterpretation. We regard education policy texts as fundamental opinions of policy-makers and as representative of the politics of policy clarification, because policy texts are 
governmental doings put into practice. Our argument aligns with the notion that policy as text comprises the agency side of work, undoubtedly situated in the framework of scholastic practices (Gale, 2006; Henry, 1993).

We contend that a consideration of education policy texts necessitates a deliberation on written inscription and achievement, arguments, as well as discourse of policy text as performance along with what is envisioned in such discourse. Gale (2006) has informed us that according to Ball (1993), policy text is accompanied by a consideration of policy as discourse, principally to explain what policy text contains with reference to "what can be said, and thought, but also who can speak, where and with what authority" (Ball, 1993, p. $14)$.

We are convinced that Ball's (1993) view explicates why Foucault (1977) suggested that "discourse is not simply that which translates struggles or systems of determination, but is the thing which, and by which, there is struggle, discourse is the power which is to be seized" (p. 110). Given Foucault's observation, policy researchers should obtain information about how individuals are visualised in their contemporary social settings. Policies should be regarded as conversational approaches, collections of actions, texts, objects, and practices that speak to broader social developments of teaching, such as the construction of the aim of teaching and the structure of the teacher (Ball, 2015). This would be comprised of two critical and connected components: the choice, breakdown and sequencing of the curriculum (content); and the deliberate organisation of learner activities by teachers (assessment and skills development). Interpreting both Foucault (1977) and Ball (2015), we realised that education policy discourse consists of communicating texts that encompass space, thought, and invention for the articulation of views regarding teacher autonomy.

With relation to our experience as educators, we are aware that education policy is inflexible; it sets out requirements regarding how schools should function and what teachers ought to do (De Klerk, 2014). This implies that the discursive foundations of education policy control teachers' educational practices and how they are situated in scholastic situations. The controlling purpose of education policy, according to Olssen et al. (2004) should be regarded as conversational personifications of the subtleties of several fundamentals that underscore social practices. Therefore, we are of the opinion that reading education policy is not an activity that involves just understanding it as the declarations of policy-makers, but also recognising, rather, that "the discursive formations they contain . . . await decoding" (Olssen et al., 2004, p. 2). Consequently, it is our intention, in applying a capabilities perspective, to analyse a South African education policy that aims to empower teachers to become agents of autonomy. No comma after aims

\section{Linking agent, agency, and autonomy}

Characterising teachers as agents demands an overview of some conceptualisations of what an agent might be. For Sewell (1992, p. 20), "humans are born with a highly universal capacity for agency." Archer's (2003) description of agents as "possessing assets ... such as 
thinking, deliberating, believing, intending and loving" (p. 2), seems to resonate with Sewell's (1992) depiction since these could be characterised as natural qualities. Giddens's (1984, p. 3) definition conveys a component of existentialism: "to be a human being is to be a purposive agent." We argue that agents are individuals who are self-reflecting, selforganising, and self-regulating. These characteristics are useful in a consideration of how teachers as agents project their life course at specific instances during their teaching practice (Bandura, 2006).

Characteristics such as being "deliberating" (Archer, 2003, p. 2), "purposive" (Giddens, 1984, p. 3) and "self-organizing" (Bandura, 2006, p. 64) can contour the intentions and intentionality that are entrenched in acts of agency that direct a human agent's life course. Sewell (1992) regarded agency as a crucial capacity that is indispensable for forming intentions. Giddens (1984), however, contended that although it has repeatedly been thought that agency can be described in terms of objectives, he argued that agency refers "not to the intentions people have in doing things, but to their capability of doing things in the first place" (p. 9).

Biesta et al. (2015) have reminded us that agency is something that people can do and not something that people can have, and that three dimensions of agency should be considered. Emirbayer \& Mische (1998) in Biesta, et al., (2015) list three essential points. First, the iterational dimension of agency has to do with the careful selection by actors of previous arrangements of action and thought. Second, the projective dimension incorporates the creative cohort of actors. Constructions of thought and action may be reconfigured innovatively in relation to actors' desires, hopes, and fears for the future. Third, the practicalevaluative dimension involves the capacity of actors to make concrete and normative decisions in response to the developing demands of current developing situations. In this paper, we regard the iterational dimension as significant. By way of example, past experiences will, through analysis, be rearticulated further on in this paper in terms of the capabilities approach with specific reference to the notions of agency and agent.

Conceptualisations of agency may expose relationships between agency and structure, that is, in this case, between teachers and schools. Drawing on Powell and McGrath (2014), we think that a focus should be on capabilities that have substance to teachers and the degree to which institutional engagements develop or narrow their capabilities. For instance, Ingersoll (2003) asserted that teachers' capacity to apply autonomy may have a progressive e $\square$ ect on how the school functions given that autonomy is reliant on which activities they can influence.

Additionally, teachers' performance in the school environment is of extreme significance to how well schools function with reference to the degree to which teachers, as well as other participants in the school, become able to control certain behaviours, make decisions, and ask questions (Ingersoll, 2003; Groener \& Andrews, 2019). It is, therefore, important to consider how agency shapes the capacities of teachers to be regarded as autonomous agents.

If teachers know how to do agency (Biesta et al., 2015), they may be positioned to become autonomous agents (De Klerk et al., 2012). Autonomy as a teacher requires skilful action that includes acting in a sensible manner, creating self-regulating teaching practices, and 
embracing opportunities to develop optimally (De Klerk et al., 2012). We believe that autonomous teachers should not be passive actors in life, but that they should, rather, be vibrant agents who establish themselves persuasively by their individual self-control because one of the goals of education policy is to promote autonomous individuals. Cuypers and Haji (2008) have explained that autonomy as an educational aim may pave the way for selfdirected individuals by offering them the freedom to make independent choices regarding their teaching practices.

Consequently, from the capability perspective, autonomy emerges as an individual's freedom to choose her or his own path of development and resist being fixed into a traditionalist view of action (Binder \& Binder, 2016). We argue that the capabilities approach could assist individuals to consider what is valuable and to pursue relevant goals as well as ensure that they make autonomous decisions regarding their own professional development since the capabilities approach offers a broad view of development that focuses on individuals' agency (Buzzelli, 2015). The capabilities approach focuses on the freedom individuals have to use their agency in order to expand their capabilities, which, in turn, can lead to greater agency. For Sen, capabilities align with agency in enabling individuals to make reasoned choices and act accordingly, while autonomy is regarded as an adequate level of competence, implying that individuals use opportunities to maximise their freedom of decision and action (Sen, 1999).

\section{Research methodology: Postmodernism}

Foucault postulated that "a postmodernist will develop actions, thought and desires by proliferation, juxtaposition and disjunction [and] prefer what is positive and multiple, difference over uniformity, flows over unities and mobile arrangements over systems" (1984, p. xiii). This view of Foucault, according to our interpretation, has, as its basis, a questioning of ultimate truths as well as a rejection of grand narratives. It is thus not surprising that Tinning (1991) interpreted Foucault's view as multiple readings or interpretations of texts that value eclecticism rather than one way of thinking about them. A referral to multiple interpretations and the rejection of ultimate truths implies that postmodernism can also be seen as a celebration and tolerance of pluralism and difference that leads to a much more ambivalent and less fixed positioning of subjectivity. From a postmodernist perspective, the subject does not exist naturally and pre-formed, but is, rather, a cultural construct, inscribed by discourses as well as the constructive power of language (Usher \& Edwards, 1994). Through language, discourse, and texts, multiple meanings can be created and re-created in ways of which we are rarely aware (Connor, 1989).

To articulate knowledge regarding teacher autonomy through the application of a capabilities perspective, the methodology we applied is supported by a constructionist epistemology. In rejecting the existence of objective truth and the validity of grand narratives, we use two personal narratives of the first author of this paper as well as analysing stipulations from the CPTD to generate understanding of the topic under study. We also draw on philosophical perspectives in offering analysis and interpretation of information. Our philosophical 
perspectives are inspired by Foucault, Kant, and Sen. While Foucault (1977) regards autonomous individuals as beings who are able to reflect independently on their teaching practices and enjoy meaningful options to act, Kant (1797/1991) argued that autonomy hinges on action based on moral reasoning, that is, on making decisions about what is right and wrong. Sen (1992) argued that capabilities have relevance to values such as efficiency, agency, and empowerment. We argue that autonomous individuals act independently while being committed to being empowered to live the life they value. Thus, to continue the debate on teacher autonomy through a capabilities perspective, we analyse below South African education policies that foreground the professional development of teachers.

\section{South African education policies for teacher development}

We analyse stipulations from four South African education policy documents that address teachers' professional development. First, The national framework for teacher education and development in South Africa (Department of Education [DoE], 2006), aims to prepare teachers appropriately to assume their important and challenging responsibilities, to permit them to improve their professional capability persistently, and to promote and deserve the reverence in which they are held by the people of South Africa. Second, the Continuing Professional Teacher Development (CPTD) (2008) policy provides for focused high quality ongoing professional development for all enumerated teachers by the South African Department of Basic Education so as to revitalize the teaching profession and recompense educators who commit themselves to the intentions of the policy (DoE, 2008). The intentions of the latter policy are to improve the professional development of teachers and to strengthen their subject knowledge base as well as enhance their teaching skills (DoE, 2008). Third, the Integrated strategic planning framework for teacher education and development in South Africa (DoE, 2011) aims to refine the quality of teacher education and development in order to improve the quality of teachers and teaching. Fourth, the Teacher professional development masterplan 2017-2022 (DoE, 2018) aims to improve teacher education and development in order to improve teachers and their teaching. Our view is that these policies aim to foster teacher development so that teachers become self-reliant and self-knowing experts or, in other words, individuals who will know how to be autonomous.

\section{The reason for policy analysis}

While policy is generally considered to be the interaction of resources, values, and interests directed through organisations and facilitated by government (Browne et al., 2018), policy analysis is not a straightforward activity because there is little agreement regarding what public policy means and how it should be understood and analysed (Peters, 2015; Sabatier \& Weible, 2014). Therefore, we agree with Olssen et al. (2004) that analysing education policy is not only comprehending its educational setting or interpreting it as a set of declarations of policy-makers, but is, rather, bearing in mind that the conversational foundations contained in such policy await analysis (De Klerk, 2014). Two kinds of policy analysis approaches come to mind. First, conventional policy analysis provides descriptions of actuality and social integration between teachers and the social world as well as the school and the social world 
(O’Connor, 2005). For example, conventional policy analysts tend to describe social problems, discuss competing policy solutions, and consider implementation problems and evaluate possible policy implementations (Scheurich, 1997). Second, an interpretive perspective is based on an understanding that the world is as it is and on appreciating the important nature of the social world at the level of individual experience (O'Connor, 2005, pp. 4-5). In this paper, we implement an interpretive perspective on policy analysis because our intention is to continue the debate on teacher autonomy from a capabilities perspective. This aligns with the interpretive approach to policy analysis because it emphasises consciousness raising and education about policy texts (O'Connor, 2005).

\section{Capabilities for teacher autonomy}

We analyse stipulations from the four policies indicated so as to provide a more systematic account of meanings that pertain to teacher autonomy. The first stipulations from DoE policy documents indicate that "when teachers themselves are integrally involved in . . reflecting on their own practice (DoE, 2006, Section 7), they "independently and cooperatively have a high degree of responsibility for their personal professional growth and the identification of their own professional needs" (DoE, 2008, Section 1). Additionally, the Integrated strategic planning framework for teacher education and development in South Africa "places teachers firmly at the centre of all efforts to improve teacher development and enables teachers to take substantial responsibility for their own development" (DoE, 2011, Section 7). Teachers, therefore, in the same way as indicated by the DoE (2011), "will define their own CPTD requirements or participate in school-initiated activities" (DoE, 2018, Section A(d)).

We argue that phrases like "reflecting on their own practice", "identification of [their] own professional needs", "responsibility for their own development" and "define their own TPD requirements" imply that teachers are afforded opportunities by these policies to make autonomous decisions regarding their own professional development. In this regard, following Frostenson (2015), teacher autonomy becomes significant for teachers' responsibility to influence their own practices and empowers them subsequently to enhance their agency as Lennert da Silva and Mølstad (2020) noted in a different context. Considering this, the first author narrates his experience.

After my appointment as a principal, I implemented a programme called share-myexperience-share-my-expertise. The purpose of this programme was to put teachers in control of programmes, events planning, chairing meetings, present workshops and manage reading clubs, amongst others. I noticed that, by participating and being in charge, teachers' managerial and leadership skills developed, almost as if they became the authors of their own stories, [in that] they became confident and unafraid to voice their opinions. By giving [them] an opportunity to take responsibility and be accountable for themselves and school programmes, they developed into individuals who could stand their own ground.

Here we can see agency becoming visible in teachers being enabled "to participate" and "be in charge" as well as being encouraged "to voice their opinions." This implies that teachers 
were allowed to do things which they could have done in the first place as Giddens (1984) has pointed out elsewhere. If teachers would engage deliberately with the available opportunities with which they are presented to have experiences, to reason, to adopt beliefs, and to act (Bevir, 1999) and if teachers would involve themselves in activities as suggested by Bevir (1999), an understanding of agency might be established. Teachers would be in a position to decide which experiences, actions, and beliefs may be regarded as acceptable or unacceptable. In doing so, teachers would then become agents who exercise agency when they resist being merely obedient followers of stipulations in education policy.

Notably, if teachers exercise choice and take responsibility for making their own decisions that will benefit the school as an educational structure, we argue that they can be deemed autonomous. Little (1995) has explained that autonomous teachers have "a strong sense of personal responsibility for their teaching, exercising via continuous reflection . . . and exploiting the freedom that this confers (p. 179). Thus, the autonomy of teachers can be improved when they take the responsibility of participating in developmental practices since in this way they generate opportunities to affirm their practices, value their lives, assert their understanding and abilities, and make their opinions heard as Ayers (2004) has noted. We agree with De Klerk (2014) that when teachers have been given the chance to become educational participants, they will exercise agency (and become individuals who can do things) in order to be regarded as autonomous agents (or individuals who can be independent) in the midst of the managed processes by which they are guided.

Second, teachers should be mindful of how to commit themselves to being considered autonomous. This requirement becomes evident in that teachers are encouraged "to continually enhance their professional competence and performance" (DoE, 2006, Section 1) while the DoE will support and facilitate a practice of determined, high quality continuing professional development for all enumerated teachers, to rejuvenate the teaching profession and to reward teachers who commit themselves to these goals (DoE, 2008, Section 2). This will mean that teachers are capacitated to "identify their own learning and professional development needs and to access opportunities to address these needs (DoE, 2011, Section $15(1)(a)$ ), and that teachers are allowed to "administer their own self diagnostic assessments in order to determine their content needs and areas of development" (DoE, 2018, Section $\mathrm{A}(3)(\mathrm{b}))$.

Derived from the above stipulations, phrases such as "continually enhance", "continuing professional development", "access opportunities" and "determine their content needs and areas of development" align with the notion of commitment. We argue that an understanding of these phrases is fundamental to teachers' commitment to providing their own learning opportunities in terms of their professional development. In another study, Goodnough (2016) asserted that teachers' commitment places them central to their own needs and in control of their development, implying that teachers may have the ability to direct their own teaching practices while they make independent choices about their work. This aligns with teachers' commitment to decide on their goals for their own professional development and the degree of choice regarding their behaviours and beliefs (Adolfsson \& Alvunger, 2017; 
Hadfield \& Jobling, 2016). Arguably, teacher autonomy as indicated by Adolfsson and Alvunger (2017), Goodnough (2016) and Hadfield and Jobling (2016) aligns with teacher agency in that teachers are positioned in terms of what they can do or achieve with reference to their development (Nguyen \& Bui, 2016). In this regard, the first author of this paper noted,

When I was Head of Department at a school, the principal usually approached all staff members to attend development courses offered by the South African Department of Education (SADoE) in a location far from our school. Teachers would not be willing and my hand would frequently rise to indicate my willingness to attend staff development courses such as curriculum changes and planning, assessment methods, and remedial work, among others. On return from such workshops, I committed myself to train the teachers at school so that they could obtain the knowledge I acquired during these staff development sessions. I would then convince our principal to invite teachers from the surrounding schools for training sessions and would afford my colleagues opportunities to take charge of presentations and skills development. Upon reflecting, I regarded my commitment to my work as valuable to me and I realised how independently I acted and how I contributed to the capacitation of colleagues so that they could also act in an autonomous way.

It is possible that teachers may be influenced by policy demands to such an extent that their choices may be guided by their personal intentions and the search for personal wellbeing. Articulated differently, individuals may be eager to invoke values other than personal wellbeing in an attempt to support the welfare of those with whom they are in association (Sen, 1985). In terms of agency and drawing on Foucault (1981/2005) as well as Pignatelli (2015), if teachers commit themselves to participate in the continual development programmes offered by the DoE, they may experience particular truths about themselves and recognise a chance to be what they are not yet. Such truths, as Foucault (1984/1987) called them, "good, beautiful, honourable, estimable, memorable and exemplary" (p. 117) may be referred to as specific aspects about how individuals value themselves and also show how they care for themselves.

Thus, to be committed, yet autonomous, teachers should position themselves in such a way as to be able to determine who they are, what they can do, and with whom they can exchange information. Consequently, drawing on Sen (1999) and reflecting on the analyses of stipulations from South African education policies, we argue that the capability approach purports that freedom is a matter of what people are able to do and to be. Freedom in terms of teacher autonomy signifies that individuals give meaning and coherence to their lives and take responsibility for the kind of people they want to become (Dworkin, 2015 in Wermke \& Salokangas, 2015). Fostering teacher autonomy, from a capabilities perspective, is illustrated in the following figure. 


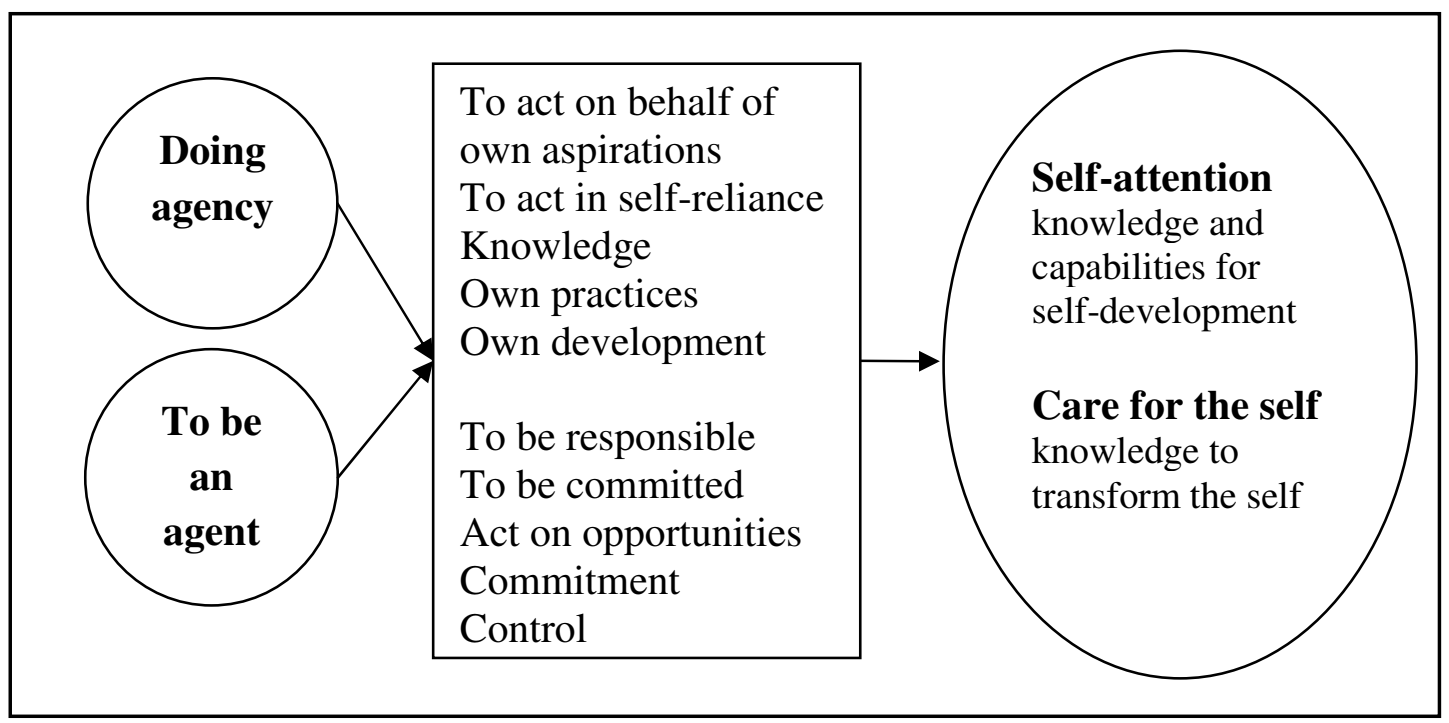

Figure 1: Doing agency and being an agent: Towards teacher autonomy

First, to exercise agency (to do), teachers should implement self-attention which relates to a form of self-constitution. This implies that teachers pay attention to their own development and that they are also integrally involved in such development while reflecting on their own practices (DoE, 2006). Consequently, self-constitution depends on teachers' ability to decrease the gap between, on the one hand, what they think about themselves and what they have to do to improve themselves, and, on the other, what activities they should engage in to get to know themselves better (Gros, 2005). Agency may become a reality when teachers act on behalf of their "own practice" (DoE, 2006, 17), their "own professional needs" (DoE, 2008 , 4), their "own development" (DoE, 2011, 3) and their "own TPD requirements" (DoE, 2018, 19). Arguably, when teachers take responsibility to know themselves better and use opportunities to develop themselves accordingly, they become agents who act in favour of their own aspirations. In doing so, they may be regarded as agents of self-attention which constitutes the rational discipline of adopting knowledge or a skill (Stiegler, 2010), and which can be regarded as an act of autonomy that correlates with self-efficacy, work-satisfaction, and self-empowerment (Lewin, 2018; Wermke et al., 2019).

Second, to help teachers to exercise agency (to do), one ideal might be to provide them with tools to enable them to act in self-reliance. This can be done when teachers act on opportunities to "enhance" (DoE, 2006, 13), "rejuvenate" (DoE, 2008, 4), "access" (DoE, 2011, 12) and "administer" (DoE, 2018, 23). When teachers act in this manner, they become agents who are committed and who take care of themselves. In this way, autonomy becomes a reality because teachers take control of rebuilding their professional values (Nica, 2015) while making "the fundamental commitment ... with fundamental characteristics, as a project of inventing, defining, elaborating, and practising a complete care of the self" (Foucault, 1984/1997, p. 281).

Teacher autonomy is possible because teachers can be empowered to develop skills, abilities for independent action, the capability for self-regulating decision-making as well as the willingness and self-reliance to make self-governing choices. For teachers to free themselves 
from educational limitations, they have to appreciate themselves well enough to break free of the bonds of self and find a way to do (agency) in order to be (an agent) autonomous in terms of their own teaching practices.

\section{Concluding remarks}

Albeit in part a compendium of South African education policies, our aim in this paper was to analyse stipulations in the CPTD on teacher development to empower teachers to become agents who foster their own teacher autonomy. Our analysis shows that teachers should be aware of how to do (perform agency) in order to be (act as an agent). For instance, if teachers understand how to engage intentionally and responsibly with opportunities outlined in South African education policies, agency will occur as they realise how to become the authors of their own teaching practices in that they are afforded opportunities to describe, analyse, and evaluate their teaching experiences (Walkington, 2005). Such action would result in teachers becoming agents because to be an agent is to intentionally make things happen through one's own actions. Also, we argued that if teachers understand how to act in self-reliance, they may be committed to participate in continual development programmes in order to become autonomous educational agents.

We support earlier findings in the academic literature that refer to policy documents from the Organization for Economic Co-operation (OECD) and the European Union (EU). Wahlström (2015) found that the OCD and EU policy documents address teacher education and teacher development from a cosmopolitan viewpoint and speak specifically about teacher empowerment and the promotion of human rights and justice in education. Similarly, in this

paper we have argued that empowerment of teachers in terms of autonomy and agency should be regarded as significant to ensure that they develop and become able to act as independent individuals We have shown that education policy encourages teacher autonomy and agency in that it aims to equip teachers to enhance their professional competence and performance continually, and to raise the esteem in which they are held.

Importantly, this study indicates that teachers need training regarding the implementation of professional development policies based on an understanding of what it means to be an autonomous teacher. Action research on this implication might be worthy research in the future.

\section{References}

Adolfsson, C. H., \& Alvunger, D. (2017). The nested systems of local school development: Understanding improved interaction and capacities in the different sub-systems of schools. Improving Schools, 20(3), 195-208.

Archer, M. S. (2003). Structure, agency and the internal conversation. Cambridge University Press.

Ayers, W. (2004). Teachers toward freedom. Beacon Press. 
Baldini, S. B. (2019). Narrative capability: Self-recognition and mutual recognition in refugees' storytelling. Journal of Information Policy, 9, 132-147.

Ball, S. J. (1993). What is policy? Texts, trajectories and toolboxes. Discourse: Studies in the Cultural Politics of Education, 13(2), 10-17.

Ball, S. J. (2015). What is policy? 21 years later: Reflections on the possibilities of policy research. Discourse: Studies in the Cultural Politics of Education, 36(3), 306-313. https://doi.org/ 10.1080/01596306.2015.1015279

Bandura, A. (2006). Toward a psychology of human agency. Perspectives on Psychological Science, 1(2), 164-180.

Barfield, A., Ashwell, T., Carroll, M., Collins, K., Cowie, N., Critchley, M., Head, E., Nix, M., Obermeier, A., \& Robertson, M. C. (2001). Exploring and defining teacher autonomy. In A. S. MacKenzie \& E. McCafferty (Eds.), Developing autonomy: Proceedings of the JALT Cue 2001 Conference, Shizuoka, Japan (pp. 217-222). The Japan Association for Language Teaching.

Baxen, J., Nsubuga, Y., \& Botha, L. J. (2014). A capabilities perspective on education quality: Implications for foundation phase teacher education programme design. Perspectives in Education, 32(4), 93-105.

Bevir, M. (1999). Foucault and critique: Deploying agency against autonomy. Political Theory, 27(1), 65-84.

Biesta, G. (2009). Education after deconstruction: Between event and invention. Counterpoints, 323, 97-113.

Biesta, G., Priestley, M., \& Robinson, S. (2015). The role of beliefs in teacher agency. Teachers and Teaching, 21(6), 624-640. https://doi.org/10.1080/13540602.2015.1044325

Browne, J., Coffey, B., Cook, K., Meiklejohn, S., \& Palermo, C. (2018). A guide to policy analysis as a research method. Health Promotion International, 34(5), 1-13.

Buzzelli, C. A. (2015). The capabilities approach: Rethinking agency, freedom, and capital in early education. Contemporary Issues in Early Childhood, 16(3), 203-213.

Binder, C., \& Binder, C. (2016). A capability perspective on indigenous autonomy. Oxford Development Studies, 44(3), 297-314.

Connor, S. (1989). Postmodernist Culture. Basil Blackwell.

Cuypers, S. E., \& Haji, I. (2008). Educating for well-being and autonomy. Theory and Research in Education, 6, 71-93. 
De Klerk, E. D. (2014). Teacher autonomy and professionalism: A policy archaeology perspective (Unpublished doctoral dissertation). Stellenbosch University, Stellenbosch, RSA.

De Klerk, E. D., Palmer, J. M., \& Van Wyk, M. M. (2012). Exploring the perceptions of preservice teachers' experiences of autonomy in transformational teaching. Journal of Social Sciences, 33(3), 271-284.

Department of Education. (2006). The national policy framework for teacher education and development in South Africa. Government Printer.

Department of Education. (2008). The design of the continuing professional teacher development (CPTD) system. Government Printer.

Department of Education. (2011). Integrated strategic planning framework for teacher education and development in South Africa. Government Printer.

Department of Education. (2018). Teacher professional development masterplan 2017-2022. Government Printer.

Forghani, N., Keshtiaray, N., \& Yousefy, A. (2015). A critical examination of postmodernism based on religious and moral values education. International Education Studies, 8(9), 98-106.

Foucault, M. (1977). The archaeology of knowledge. Tavistock.

Foucault, M. (1979). The history of sexuality (Vol.1). (R. Hurley, Trans.). Allen Lane.

Foucault, M. (1984). The order of discourse. In M. Shapiro (Ed.), Language and politics (pp. 108-138). New York University. (Original work published 1971)

Foucault, M. (1985). The use of pleasure: The history of sexuality (Vol.2). (R. Hurley, Trans.). Random House. (Original work published 1984)

Foucault, M. (1987). "The ethic of care for the self as a practice of freedom": An interview with Michel Foucault on January 20, 1984." Philosophy and Social Criticism, 12(3), 112-131. (Original work published 1984)

Foucault, M. (1989). An aesthetics of existence. In S. Lotringer (Ed.), Foucault live (pp. 3543). Semiotext(e). (Original work published 1980)

Foucault, M. (1997). The ethics of the concern for self as a practice of freedom. In P. Rabinow (Ed.), Ethics, subjectivity and truth. Essential works of Foucault (Vol. 1). (pp. 281-301). New Press. (Original work published 1984) 
Foucault, M. (2005). The Hermeneutics of the Subject: Lectures at the College de France, 1981-1982. F. Gros (Ed.) (G. Burcell, Trans.). Picador. (Original work published $1981 / 1982)$

Frostenson, M. (2015). Three forms of professional autonomy: De-professionalization of teachers in a new light. Nordic Journal of Studies in Educational Policy, 1(2), 20-29.

Gale, T. (2006). Policy trajectories: Treading the discursive path of policy analysis. Discourse: Studies in the Cultural Politics of Education, 20(3), 393-407.

Giddens, A. (1984). The constitution of society: Outline of the theory of structuration. University of California Press.

Goodnough, K. (2016). Professional learning of K-6 teachers in science through collaborative action research: An activity theory analysis. Journal of Science Teacher Education, 27, 747-767.

Groener, Z., \& Andrews, P. (2019). Agency, access and barriers to post-school education: The TVET college pathway to further and higher learning. Journal of Vocational, Adult and Continuing Education and Training, 2(2), 43-60. https://doi.org/10.14426/jovacet.v2i2.71

Gros, F. (2005). “Course context.” In F. Gros (Ed.), The hermeneutics of the subject (pp. 507-550). Picador.

Hadfield, M., \& Jopling, M. (2016). Problematizing lesson study and its impacts: Studying a highly contextualized approach to professional learning. Teaching and Teacher Education, 60, 20-214.

Henry, M. (1993). What is policy? A response to Stephen Ball. Discourse, 14(1), 102-105.

Hill, T. E. (1991). Autonomy and self-respect. Cambridge University Press.

Ingersoll, R. M. (2003). Who controls teachers' work? Power and accountability in America's schools. Harvard University Press.

Jodamus, J. (2017). "Make the circle bigger": Alternate discourses of identity construction in black theologies. Journal for the Study of Religion, 30(2), 207-227.

Kant, Immanuel. 1991. The Metaphysics of Morals. Translated by Mary Gregor. Cambridge University Press. (Original work published 1797)

Keddie, A., \& Mills, M. (2019). Autonomy, accountability and social justice. Stories of English schooling. Routledge. 
Lennert da Silva, A. L., \& Mølstad, C. E. (2020). Teacher autonomy and teacher agency: A comparative study in Brazilian and Norwegian lower secondary education. The Curriculum Journal, 31(1), 115-131.

Lewin, D. (2018). Review of reconstructing “education" through mindful attention: Positioning the mind at the center of curriculum and pedagogy, Oren Ergas. Studies in Philosophy and Education, 37, 315-321. https://doi.org/10.1007/s11217-018-9603-x

Little, D. (1995). Learning as dialogue: The dependence of learner autonomy on teacher autonomy. System, 23(2), 175-182.

Mausethagen, S., \& Mølstad, C. E. (2015). Shifts in curriculum control: Contesting ideas of teacher autonomy. Nordic Journal of Studies in Educational Policy, 2, 30-41.

Miller, J. (1993). The passion of Michel Foucault. Anchor.

Mølstad, C. E. (2015). State-based curriculum-making: Approaches to local curriculum work in Norway and Finland. Journal of Curriculum Studies, 47(4), 441-461.

Nguyen, H. T. M., \& Bui, T. (2016). Teachers' agency and the enactment of educational reform in Vietnam. Current Issues in Language Planning, 17(1), 88-105.

Nica, D. (2015). Nietzsche and Foucault on self-creation: Two different projects. Philosophy Series, 64(1), 21-41.

Nussbaum, M. (1992). Human functioning and social justice: In defense of Aristotelian essentialism. Political Theory, 20(2), 202-246.

O'Connor, M. K. (2005). Policy archaeology: A qualitative approach to policy analysis. Paper presented at the First International Congress of Qualitative Inquiry. University of Illinois, Urbana-Champaign.

Olssen, M., Codd, J., \& O’Neill, A. (2004). Education policy: Globalization, citizenship and democracy. SAGE.

Parker, G. (2015). Teachers' autonomy. Research in Education, 93(1), 19-33.

Peters, B. (2015). Advanced introduction to public policy. Edward Elgar Publishing.

Pignatelli, F. (2015). Ethical leadership development as care of the self: A Foucauldian perspective. Studies in Education, 12(2), 198-213.

Powell, L., \& McGrath, S. (2014). Advancing life projects: South African students explain why they come to FET colleges. Journal of International and Comparative Education, 3(2), 213-226.

Rousseau, J. (1761). Julia: Or, the new Eloisa. Marc-Michel Rey. 
Rytzler, J. (2019). Turning the gaze to the self and away from the self - Foucault and Weil on the matter of education as attention formation. Ethics and Education, 14(3), 285-297.

Sabatier, P., \& Weible, C. (2014). Theories of the policy process. Westview Press.

Scheurich, J. J. (1997). Research Method in the Postmodern. The Falmer Press.

Sen, A. K. (1973). "Behaviour and the concept of preference. Economica, 40, 241-259.

Sen, A. K. (1985). Goals, commitment, and identity. Journal of Law, Economics and Organization, 1(2), 341-355.

Sen, A. K. (1992). Inequality re-examined. Clarendon Press.

Sen, A. K. (1999). Development as freedom. Oxford University Press.

Sewell, W. H. (1992). A theory of structure: Duality, agency, and transformation. American Journal of Sociology, 98(1), 1-29.

Smith, R. C. (2001). Learner and teacher development: Connections and constraints. The Language Teacher, 25(6): 43-44.

Stiegler, B. (2010). Taking care of youth and the generations. (S. Barker, Trans.). Stanford University Press.

Tinning, R. (1991). Teacher education pedagogy: Dominant discourses and the process of problem setting. Journal of Teaching in Physical Education, 11, 1-20.

Tobias, S. (2005). Foucault on freedom and capabilities. Theory, Culture \& Society, 22(4), $65-86$.

Usher, R., \& Edwards, R. (1994). Postmodernism and education. Routledge.

Wahlström, N. (2015). Transnational policy discourse on teacher education: A cosmopolitan perspective. Policy Features in Education, 13(6), 801-816.

Walkington, J. (2005). Becoming a teacher: Encouraging development of teacher identity through reflective practice. Asia-Pacific Journal of Teacher Education, 33(1), 53-64.

Wermke, W., \& Forsberg, E. (2017). The changing nature of autonomy: Transformations of the late Swedish teaching profession. Scandinavian Journal of Educational Research, 61(2), 155-168.

Wermke, W., \& Höstfält, G. (2014). Contextualising teacher autonomy in time and space. A model for comparing various forms of governing the teaching profession. Journal of Curriculum Studies, 46(1), 58-80. 
Wermke, W., Rick, S. O., \& Salokangas, M. (2019). Decision-making and control: Perceived autonomy of teachers in Germany and Sweden. Journal of Curriculum Studies, 51(3), 306-325. https://doi.org/ 10.1080/00220272.2018.1482960

Wermke, W., \& Salokangas, M. (2015). Autonomy in education: Theoretical and empirical approaches to a contested concept. Nordic Journal of Studies in Education Policies, $1(2), 1-6$.

Wilches, J. (2007). Teacher autonomy: A critical review of the research and concept beyond applied linguistics. Íkala, Revista de Lenguaje y Cultura, 12(18), 245-275. 